Research Article

Open Access

\author{
Georgina Tsolidis*
}

\title{
Historical Narratives of Sinophobia - Are these echoed in contemporary Australian debates about Chineseness?
}

https://doi.org/10.2478/jcgs-2018-0004

\begin{abstract}
Historically, Australianness has been defined in contradistinction to its location - a British bastion in the Asia-Pacific region. A fear of being swamped by the Chinese - the 'yellow peril' - prompted federation, and a restrictive migration policy aimed at making Australia white. Thus, sinophobia has been significant in the national imaginary. This paper discusses how contemporary representations of Chineseness may be echoing this historic narrative of fear about being overrun. This is explored in the context of China's shifting global significance and Australia's growing economic relationship with China.
\end{abstract}

Keywords: Australia; sinophobia; Chineseness; narratives of fear.

\section{Introduction}

In 2014, two Australian federal senators, Clive Palmer and Jacqui Lambie, made separate statements through the media describing the Chinese as 'mongrels' and 'bastards' who wanted to 'take over' their country and 'enslave' Australian children and grandchildren. These comments were lampooned in the press, and Palmer retracted and apologised for his comments very soon after they were made. The senators' comments drew on well-worn tropes within narratives of Australianness based on sinophobia and its strong presence in Australian history. Fear of the Chinese was the bulwark of restrictive migration policy, often referred to as the White Australia Policy, which ushered in Australian Federation in 1901. The aim of this paper is to consider whether sinophobia continues to play a part in contemporary Australia, albeit nuanced, in response to very different imperatives brought about by China's global economic ascendancy.

Contemporary global economic imperatives herald China as one of the most influential economies, and Australia has been a beneficiary of its growth. China has become Australia's number one trading partner, accounting for $22.6 \%$ of total exports and $15.3 \%$ of imports (Yuan 2014). This situation has created a need for Australia to walk a fine diplomatic line between China and its traditional allies, Britain and the USA, particularly when differences occur over geopolitical issues within the region. Australia has had some success enacting middle-power diplomacy that provides a conduit for larger players to channel their priorities into the Asian-Pacific region through, for example, advocating China's entry into APEC (Rudd 2011).

Australia's relationship with China and Chinese migration has been pivotal to its imagined nationhood (Fitzgerald 2007). The fear of being swamped by Chinese migrants and the implications of this on the labour market meant that there was wide-ranging support for the so-called White Australia Policy, including support from the workers' movement. The same fear is echoed in Palmer and Lambie's comments referred to at the beginning of the paper. However, in the contemporary context, there is concern about Chinese

*Corresponding author: Georgina Tsolidis, Adjunct Professor Alfred Deakin Institute for Citizenship and Globalisation.

E-mail: georgina.tsolidis@deakin.edu.au

Ә Open Access. (c) 2018 Georgina Tsolidis, published by Sciendo. (C) Br-Nc-ND This work is licensed under the Creative Commons Attribution-NonCommercial-NoDerivatives 4.0 License. 
investment and property ownership as well as migration and labour-force participation. The place of the Chinese in the national imaginary has stood seemingly undisturbed by more general debates about settlement policies, which were introduced in response to migration, mainly from Europe after World War II. This period of rapid population shift did not involve large-scale migration from China. The Australian Chinese community, which migrated earlier, had established itself already. The election of the Whitlam government brought with it the final stage of the dismantling of restrictive migration, the formal adoption of multiculturalism and the recognition of the People's Republic of China. Currently, China and India have replaced the UK as the source of Australia's greatest number of migrants (Markus 2015).

Contemporary Chinese migration and surrounding debates are triggered by shifts in Chinese rather than Australian economic and foreign policy (Jakubowicz 2011). It is worthwhile exploring these issues in tandem in order to understand historic sinophobia in contemporary Australia given global economic realignments. We also need to consider how a backlash against multiculturalism, albeit triggered by Islamophobia, may be having an impact on the way cultural diversity and migrant groups, such as the Chinese, are being perceived. As a way of engaging with these issues, a brief overview of Australian multiculturalism is presented in the next section of the paper.

\section{2 'Multicultural’ Australia}

Debate continues on how best to understand the relationship between ethnicity and nation (van Reekum, Duyvendak and Bertossi 2012). This debate is relatively pronounced in settler societies such as Australia. In Australia, the imagined nation assumes migration and therefore a population that includes groups of culturally distinct people. Such societies are distinguished from those that have an entrenched historical narrative that conflates language, ethnicity and nation. Australia has been described as an exemplar of a settler-colonial country - a country made up of migrants needing to resolve a colonialist relationship with the indigenous populations (van Krieken 2012). This status is understood as emblematic of nations that rely on 'thinner' conceptions of national culture, which in turn are linked to liberal discourses of tolerance and cosmopolitanism. In Australia, the liberal discourses of tolerance and cosmopolitanism that mark this 'thinner' sense of national culture are connected with the policy of multiculturalism (Kymlicka 2010, Moran 2011).

Multicultural policy was introduced formally in the early 1970s, which was a time of social change in Australia. Along with policy designed to support gender equality and provide more recognition for Indigenous Australians, multiculturalism was understood as part of a more general and progressive political agenda introduced by the incoming Whitlam Labor Government. Multiculturalism was a response to post World War II migration, predominantly from southern Europe, which has left multiculturalism strongly associated with the Italian and Greek communities and those from former Yugoslavia. Multicultural policy worked off a social reform agenda instigated through these communities to service an increasingly alienated and marginalised migrant population. Increasing politicisation was becoming evident through industrial action, most notably the nine-week strike and riots at the Ford factory in Melbourne in 1973, in which migrants played a particularly militant role and failed to be placated by their union leader, albeit a member of the Australian Communist Party (Curthoys and Markus 1978, Armstrong 2011). The recognition that mainstream welfare provision was not meeting the needs of ethnic minorities had spawned a range of community-based organisations that agitated for state support for ethno-specific welfare provision (Papadopoulos and Moraitis 2006). It was also becoming apparent that minority students were not being given appropriate education provision (Foster and Stockley 1998).

Australian multiculturalism has traditionally received support from Liberal and Labor governments. Various governments have appointed key policy bodies that channel different priorities (Jakubowicz 2015) and allocate sparse funding to suit particular political priorities (Tsolidis 2014). Despite these differences, there have been core elements of the policy on which there has been agreement. These elements are tolerance of difference, respect for equality and adherence to existing social institutions. Legal institutions, 
as well as those linked to parliamentary democracy, for example, the primacy of the English language and religious freedom, have their heritage in Britain and are represented as the cornerstones of the Australian way of life and as such are seen as beyond compromise. Migrants are expected to adhere to these core values and ways of living but beyond this, they may practice their religions and customs and maintain distinct cultural identities. Unsurprisingly, there has been robust critique of an operationalised multiculturalism linked to culture and tolerance of the cultural difference that operates at the peripheries of society. Commentators have debated whether it is possible for multiculturalism to challenge systemic racism and inequality (Hage 1998).

\subsection{Australian racism}

Migration patterns have shifted over time. Whereas once preference was given to British migrants and those from countries considered the 'next best option', such as the Baltic States in the post World War II era, the Australian population has become increasingly diverse. Today, people arrive in Australia from many ethnic and religious backgrounds including those who have been more commonly racialised. Within the national imaginary, the length of residency of any minority group is said to make them familiar and eventually they become accepted by the wider population. Once migrants, regardless of how unfamiliar they are initially, have 'done their time', they will in turn be accepted by the wider population (Brett and Moran 2011). This is the myth of tolerance and assimilation that flies in the face of evidence that particular communities experience intergenerational racism that is not accounted for within the discourses of multiculturalism (Hage 2003). The view that minorities can become like the rest of the population is bolstered by the diffidence to name racism.

Migrants associated with Islam and migrants from the Middle East have experienced sustained racism exacerbated by the events of September 2001 (Poynting 2006). These communities were targeted in the notorious 2005 riots on the beaches of Cronulla outside Sydney. These events precipitated a political backlash against multiculturalism. This backlash relied on a narrative of fear that the values that sat at the heart of society were under threat. At the time, senior members of the Australian Liberal Government made public pronouncements about the failure of 'mushy and misguided' multiculturalism to ensure social cohesion. They argued that deportation should be considered, including for those born in Australia who were associated with the Middle East (Tsolidis 2014, Moran 2011). Ironically, the Australian government has put measures in place to stop people leaving the country and travelling to countries such as Syria for fear that they will join extremist movements there and return radicalised and therefore dangerous (Cox 2014).

We are now in what is described as a post-multicultural phase, despite the 'super diversity' that exists in many nations (Vertovec 2010). Multiculturalism is now more commonly portrayed as a threat to the social institutions represented as guardians of an Australian way of life and thus to social cohesion. Alternatively, it is represented as lacklustre; a toothless sop to the ethnic rights movement that has transformed into a 'multicultural industry'. Instead, integrationism is again gaining currency (Meer and Modood 2014, van Krieken 2012). This provides politicians with a means of placating new right agendas, feeding on a fear that the ways of life that link nation, language and ethnicity will not persevere. Lentin (2014) argues that the backlash against multiculturalism reiterated by politicians, members of the intelligentsia and the mainstream media is inscribed by a post-racial logic. This move away from biological categories of race to cultural and religious categories of difference makes it somehow more acceptable to call for exclusion or integration. Increasingly, the individual is held responsible for their capacity to develop active citizenship with state-sponsored support diminishing. Without recourse to intrinsic categories of difference, minorities can be represented as choosing to remain distinct and, as such, a threat to what is perceived to be a common way of life. This shifts the onus onto those experiencing exclusion and provides racism with an acceptable veneer because it deals with culture in a seemingly 'colour-blind' way.

The Chinese have been a traditionally racialised group who have faced greater scrutiny about entering Australia than others. They have been confronted by the historical representation of the 'yellow peril' or 
the fear of Australia being swamped by the 'yellow hordes'. In this sense, their experience of settlement in Australia predates debates about multiculturalism and relates more poignantly to discourses of whiteness (Fitzgerald 2007). The racialisation of the Chinese relies on specific narratives of fear that places them in a historically distinct category.

\subsection{Narratives of fear}

Narratives of fear are a strong undercurrent within Australian history. Who needs to be feared and why has been nuanced differently in response to various historical events and the representation of these events by different governments. Nonetheless, sinophobia has remained apparent. Historically, Australia's desire to remain a British bastion in the Asia-Pacific region has fuelled a state of siege mentality whereby the country's geographical location has formed the idea that it is vulnerable to being overrun by Chinese migrants who would dissipate this British heritage. This line of argument is commonly associated with sinophobia as it was promulgated in the 19th century with regard to the development of the White Australia Policy.

Tudor (2003) argues that fear is a cultural manifestation as much as it draws on essential psychosocial and physiological dimensions. Fear has been used to embed social control into the way people think, feel and behave. What is feared responds to cultural scripts rather than individual nature. People are imbued through social and historical practices with a sense of what needs to be feared in any particular context and how to react to and express this fear. So although fear has an emotional dimension, it is triggered by particular cultural transfigurations. Tudor provides a heuristic framework for understanding the sociological dimensions of fear. He puts forward analytical categories, each of which contain a number of dimensions. The first analytical category is macroscopic and refers to structure. This category refers to environments, cultures and social structures. The second analytical category relates to individual agency and includes bodies, personalities and social subjects. Tudor's argument as it pertains to cultures and social structures of fear is the most relevant to the argument being developed here. He argues that culture offers us a way of making sense of our lives and provides a repertoire of values, presumptions and memories that we can draw upon for explanation. 'Indeed, the very constitution of the ways in which we experience and articulate fear is significantly dependent upon the channels of expression made available to us by our cultures' (Tudor 2003, p. 249). Additionally, social structures are the vehicles through which we interact with each other and are formed by the predictable routines that foreshadow our social activities. Changes in these social structures can lead to fear and anxiety because assumptions about our future lifestyles or expectations can be seen as threatened.

Ferudi (1997) argues that because fear is socially constructed, it can be promulgated by 'entrepreneurs of fear'. They are people who have a vested interest and support this interest through fear mongering, including through the media. Altheide (2002) pays particular attention to the role of media entertainment, which he argues has made formats that rely on familiar fear. Heightened emotions and excitement are used, and an existing narrative locks in victims and villains. Discourses of fear are part of the armoury of neoliberalism, and significantly, these discourses can instil a sense of identity at a time when obvious forms of identity are breaking down. Discourses of fear personalise social problems and make social control as a means of allaying fear more acceptable.

In his discussion of fear, Skol (2010) continues Altheide's argument about how fear feeds social control. He extols the importance of postmodernity and its reliance on the iconocentrism. Instead of linear forms of communication, icons rely on metaphors that condense and link images that can be repeated and taken into a range of modes of communications, for example, the repeated drawing together of 'Middle East' 'terror', '9/11' and the image of a plane hitting the twin towers. Iconocentric or image-based communication dominates because of the shift away from paper to electronic modes. It grows out of our familiarity with screens, initially television and subsequently computer screens. The repetition of powerful images instils a mass consciousness, within which reality and representation become blurred. 'Such enormous changes would presumably produce generalised and diffuse anxieties, which people often displace onto more manageable and concrete entities-scapegoats of all kinds' (Skol 2010, p. 18). 
Within Australian culture, a discourse of fear focusing on the Chinese as a threat has operated historically. Assumed to be incompatible with a British or Australian way of life, the Chinese have been represented as having the potential to overrun the country, hence the need for restrictive migration. Australia's unpopular decision to conscript young soldiers to fight in Vietnam was explained by the need to halt the 'red peril'. The Chinese were communists on their door step, and the domino theory drew a line from China through Asia that had the potential to reach Australia. Echoes of this narrative can be heard in Senator Lambie's comments that the 'communist Chinese' were a threat to nationhood and threatened to enslave Australian grandchildren through a military invasion (AAP 2014). Similarly, this fear of being overrun reverberates through some recent debates about home ownership. Whether or not young Australians can afford to purchase a home has been linked to a boom in investment properties, particularly those purchased by Chinese investors (ABC 2017). Narratives of fear have surrounded the Chinese in more or less graphic ways over the years. This is a cultural script imbued through social and historical practices. In the following section of the paper, some insights are provided into Chinese settlement in Australia that make evident the historical nature of this cultural script.

\subsection{Chinese Settlement in Australia}

The fear of Australia being overrun by the Chinese has been exaggerated by geographic proximity and the belief that the Chinese were incompatible with British-inspired values and ways of life. The 1925 Year Book Australia (ABS), which has remained on the Australian Bureau of Statistics website with a disclaimer that it may be offensive to some people, provides a chilling sense of how Chinese migration has been perceived. The Year Book reported that indentured labourers from China were brought into Australia as early as 1845, five years after transportation was abolished because pastoralists required these 'coolies' to labour. Few Chinese migrants arrived independently until the Gold Rush period. In Victoria, where the richest gold reserves were found, the number of Chinese migrants peaked in 1857, when 25,421 people were recorded as entering, of whom only three were women. The 1925 Year Book describes the various efforts made by each colony to restrict Chinese migration. These culminated in uniform legislation introduced in 1881 and strengthened in 1888, which reduced the number of arrivals. Four reasons are given for the need to restrict Chinese migration: numbers of Chinese had increased in the north west of Australia, growing opposition by the labour movement to cheap labour, increases in small pox attributed to the Chinese and cases of leprosy among migrants and fear of a larger 'influx' because of restrictions introduced by the USA. The incompatibility of Chineseness and Australianess was taken for granted.

The tenor of the discourse offered in the 1925 Year Book is subtler than that which prevailed during the Gold Rush period when the Chinese were vilified and physically attacked. Notable were a range of cartoons that appeared in the press, including the infamous 'The Mongolian Octopus Has His Grip on Australia' published in The Bulletin in 1886. A Chinese man's face sat on top of an octopus' body. Each of the eight tentacles represented a problem that was linked to the Chinese; these were immorality, disease, gambling, corruption, drug taking and the threat of cheap labour. The racialisation of the Chinese focused on men. The extraordinarily small numbers of women who came to Australia from China fuelled the vision of Chinese men as predatory, immoral and a threat to Australian women. The cartoons of the time depicted Chinese men as the cause of the moral downfall of Australian women and linked this to opium taking. Australian women who 'consorted' with Chinese men were deemed 'fallen', and their entry back into mainstream society became impossible. The 1925 Year Book recorded the following statement: 'The extent to which Chinese blood has been mixed with the white race is shown by the figures for half-castes in the preceding tables'. The table registered the first number in 1901 as 3,090.

Unsurprisingly, the claims that the Chinese introduced diseases and were a threat to women have been contested. Welch (2003) argues that the undesirable practices that were associated with the Chinese were already common on the gold fields. Small pox, for example, existed on the gold fields prior to the arrival of the Chinese, and immorality in the form of prostitution and child abuse was similarly apparent, including in England. Welch places the oft-cited link between opium and the Chinese in the context of 
the opium trade in India, which had financed the building of empire. He argues that the need to protect income generated by opium caused the change in attitude towards the Chinese because they were targeted to become the next major market. Selling opium to the Chinese demanded a psychological shift in ideas about them. Whereas once the English had lauded the Chinese as a great civilisation, they were now vilified and demeaned so that selling opium to them became somehow more possible and acceptable. This shift from respect to demonization spilt over into Australia. The Chinese were being scapegoated, and their vilification relied on linking them to issues that conjured and sustained fear.

The need to exclude the Chinese on racial grounds was pronounced openly by politicians. This was evident in the efforts made to stop people disembarking from ships in Melbourne and Sydney in 1888. Ships arriving in Melbourne and Sydney carried Chinese passengers, many of whom held naturalisation papers and had paid the poll tax required to disembark. Nonetheless, the Burambeet and Afghan were placed in quarantine in Sydney and passengers were stopped from disembarking. This matter was contested by Chinese passengers and reached the Supreme Court. Despite the Supreme Court's ruling in favour of the Chinese passengers, Parkes, the Premier of New South Wales at the time, declared that it was a 'sacred obligation' to protect the British type within Australia from the alien Chinese. He established them as 'alien' on the basis of their customs, religion, lack of familiarity with Australian jurisprudence and lack of wives. Most importantly, however, for Parkes, it was their 'Asiatic blood' that made them alien; 'for although they [colonialists] might very freely admit the admixture of the blood of European peoples, they did not want any Asiatic infusion' (Parkes cited in Finnane 2014, p.167). Finnane (2014) argues that although much has been made of this incident as an exemplar of restrictive immigration and racism, it needs to be considered anew. Rather than reinscribing the common view of the Chinese as victims of racism, it exemplifies their resilience. By taking action through to the Supreme Court, these Chinese passengers were able to emphasise their subjectivity and the fact that they 'thought of themselves as settlers and sought advantage from that status' (Finnane 2014, p.169).

The theme of economic competition had been ongoing and was a strong impetus for the Lambing Flat riots in 1861. During these riots, Chinese miners were attacked and the non-Chinese rioters then proceeded to attack the police camp after police were sent to quell the unrest. The Lambing Flat banner emerged during this period, a hand-painted banner. It combined a depiction of the southern cross star constellation made famous during the earlier Eureka Stockade, the cross of St Andrew and the words 'no Chinese' and 'roll up', intended as a call to assemble. The Chinese were considered a labour threat on the gold fields, and the Lambing Flat banner was considered as a symbol of the exclusivity advocated by the labour movement. Keeping the Chinese out of Australia was a major impetus for federation in 1901, the same year the Immigration Restriction Act was adopted, for which the support of the labour movement was necessary (Selth 1974, Curthroys and Markus 1978). The Eureka symbol remains in use today and is adopted by some in the labour movement as a symbol of radicalism. It is also adopted by some within anti-immigration and neo-right groups.

\subsection{Entrepreneurship and sinophobia}

Hage (2014) argues that racism proceeds through cycles that include accelerated moments of aggressive violence. These violent incidents are followed by 'a more gentle mode of normalisation and routinisation of racialised forms of interaction.' (p. 234). The subsequent phase of the racist cycle is more nebulous and thus leaves those experiencing it with less capacity to recognise and counter the racism. The anti-Chinese riots during the Gold Rush period are identified by Hage as one of the moments of aggressive violence that occurred. This was a time when existential racism operated. This racism expressed a disgust for racialised groups and can be recognised in the graphic cartoons depicting the Chinese at the time, which were published in the press discussed earlier. It is worth considering Hage's argument that racism proceeds through more or less violent cycles with reference to the contemporary context and the possibility that racism against the Chinese is more nebulous and thus more difficult to identify and counter. 
Anti-China sentiment has been expressed in a number of countries. This is sometimes linked to domestic policy, such as the treatment of Muslim minorities in China, which fuelled demonstrations in Turkey (Tasch 2015). In Zambia, it has been linked to poor working conditions offered to workers in Chinese-run mines (Aidoo 2016). In Vietnam, it is triggered by disputes over sovereignty in the South China Sea (Aljazeera 2016). Benton and Gomez (2014) argue that there is a rise in sinophobia that is linked to the shift in the status of China, which is emerging as an economic and political power. China's new status is fuelling fear and subsequent unrest, which is having an impact on Chinese communities living outside China. It is also argued that in some cases, it is Chinese migrant workers who are being scapegoated despite the fact that many experience appalling working conditions in countries such as the UK and Italy (Bin Wu and Hong Liu 2014).

Chinese entrepreneurship is evolving in new and multifaceted ways that are having an impact on economies around the world. In Australia, the state of the economy is sometimes evaluated on the basis of the Chinese economy and its capacity to absorb Australian primary resources such as coal and iron ore. The argument is made that if the Chinese economy slows, so does the Australian economy (Jericho 2014). Chinese involvement in the Australian economy has been showcased in some political debates about the Chinese and what is expressed by some as the buying up of Australia, including land, housing and influential contracts for development. The Australian dream of home ownership is becoming less realistic for younger people. Many of them can no longer afford entry-level properties, particularly in Sydney and Melbourne. In the most recent federal election campaign, Prime Minister Turnbull raised eyebrows when he stated that young couples wishing to buy their first home needed to call on their parents for monetary assistance (Bourke 2016). Housing affordability remains a top issue of concern for the generation born in the 1980s and 1990s. In this climate, the impact of overseas buyers, of whom the Chinese are the most significant, has become a controversial issue with some commentators claiming that because of Chinese pressure, the Australian dream of home ownership is being thwarted, particularly for young first homebuyers who are being priced out of the market (Laurenceson 2014). Further to this, the unprecedented interest in the Australian property has unleashed an overabundance of poorly designed and built high-rise apartments (Birrell and Healy 2013). Chinese who live overseas are often the owners of such apartments, which are then let out to Chinese students or contract labourers who live in overcrowded situations, which can include sleeping on balconies and cooking in bedrooms. A fire in a Melbourne high-rise apartment brought these practices into focus (Dow 2015; Vedelago and Houston 2015).

Between 2009 and 2012, the Australian government approved 380 investment proposals from China, worth more than $\mathrm{A} \$ 80$ billion. China remains the ninth largest source of overseas investment in Australia. A failed bid to acquire an $18 \%$ shareholding in Rio Tinto by a Chinese company and the refusal to allow Huawei to bid for Australia's National Broadband Network contract have made evident some sensitivity within Australia about levels of investment by Chinese state-owned enterprises. During the recent election, a Chinese bid to buy Australia's largest cattle station (39,000 square miles) was blocked by the Prime Minister because it was deemed to be 'against the national interest' despite his conservative government's support of overseas investment (Hunt 2016). Additionally, there has been concern within China about how Chinese investment has been represented by the Australian media and its role in precipitating fear about a Chinese economic takeover (Yuan 2014). More recently, debates about Chinese influence in Australia have extended to political influence and the capacity of the Chinese Communist Party to influence policy and use the Chinese diaspora in Australia to pursue its agendas (SMH 2017). There has also been discussion about a book outlining Chinese influence in Australia withdrawn from publication under Chinese pressure (Greene, 2017).

\subsection{Chinese diaspora}

The shifting importance of China globally is having an impact on the Chinese diaspora. The rise of China economically and politically has prompted the emergence of a contemporary view of pan-Chineseness (Brenton and Gomez 2014). Some commentators suggest that the Chinese diaspora may act as a lobby group 
for Chinese interests in other countries (Hunt 2016, Mulligan 2016). Such arguments need to be considered in relation to notions of the diaspora more generally and whether minorities such as the Chinese can ever escape their representation as Chinese living in Australia rather than Chinese Australians. For some minorities, particularly those who are visibly different, they can remain linked to their homeland in the public imaginary, regardless of their length of residency in their country of settlement. The inability to consider these minorities as other than Chinese is strengthened by an overemphasis on their appearance and circulated stereotypes of what it means to be Chinese.

According to the Scanlon national survey, Muslim minorities remain the group that is met with the most suspicion within Australia. According to this survey, there has been a decline in the number of people experiencing discrimination because of their skin colour, ethnicity or religion between 2013 and 2015. Nonetheless, the survey indicates that according to birthplace, some groups do experience discrimination. More than 14,000 respondents were involved in the national survey between 2007 and 2015. Those born in India and China experienced the highest discrimination at $28 \%$ and $25 \%$ respectively, relative to those born in other countries (8\% UK, 9\% Germany, 12\% Italy, 12\% Australia, 14\% South Africa and 17\% NZ) (Markus 2015). Additionally, individual cases of racism against Chinese Australians have been reported in the media. Recent examples of this include the Mayor of Darwin who had racist graffiti painted on her home (Chew 2016) despite her family being in Australia since the 1800s. There is a lingering residue of ill feeling about the treatment of Chinese in Australia, including the restrictive migration policy of the past. The Asian Australian Alliance was founded in 2013 with one of its aims to secure a government apology for the so-called White Australia Policy (Mulligan 2016). We need to consider whether shifting dynamics between China and Australia are likely to affect the Chinese diaspora, particularly if there is an economic downturn and Australians can no longer assume a particular life style, such as home ownership. There is also the possible rise in neo-right movements and how this might affect groups like the Chinese, which have been racialised and considered a threat historically.

\section{Conclusion}

Fear is a cultural manifestation, and what is feared responds to cultural scripts. People are imbued through social and historical practices, with a sense of what needs to be feared in any particular context and how to react to and express this fear. In Australia, narratives of fear have been promulgated in relation to the Chinese historically. Because of the proximity of China to Australia, the fear of being swamped by so-called cheap labour led to restrictive migration policies, which continue to cause angst for the Chinese Australian diaspora today.

Contemporary China is an economic powerhouse and a key driver of the Australian economy. This has led to a shifting view about the role of China, and we need to consider whether this will have an impact on members of the Chinese diaspora because of notions such as pan-Chineseness. Although discrimination against the Chinese in Australia is not often played out in obvious ways, as it is with Muslims, there is a need to explore the role of historic sinophobia and its possible influence on contemporary understandings of Chineseness. We need to consider whether there may be a burgeoning of such images and if these reiterations of the Chinese as a threat link to new and more nebulous forms of racism. Is it possible that the historical fear of being swamped, which provided the rationale for discriminatory migration policies, is being echoed in recent comments about Chinese economic takeover through investment and the purchase of property ownership? It is conceivable that this contemporary narrative is recirculating historical tropes of what it means to be Chinese in the national imaginary and this could have a serious impact on Australia's Chinese diaspora. 


\section{References}

AAP. 2014. ' Palmer United Party's senator Jacqui Lambie says Australia must double the size of its military to counter the threat of a Chinese invasion.' SBS. Accessed 14 September, 2016. http://www.sbs.com.au/news/article/2014/08/19/ lambie-warns-chinese-invasion- threat- 0 .

ABC. 2017. 'Are Chinese buyers driving up Australia’s housing prices?’ ABC News. Accessed 7 February, 2018. http://www. abc.net.au/news/2017-10-06/impact-of-chinese-buyers-on-australian-house-prices/9021938

ABS. 1301.0 Year Book Australia, 1925 The Chinese in Australia, Accessed 7 September, 2016. http://www.abs.gov.au/ AUSSTATS/abs@.nsf/Previousproducts/1301.0Feature\%2 0Article21925?opendocument\&tabname=Summary\&prodno= 1301.0\&issue $=1925$ \&num $=$ \&view $=$

Aidoo, J. 2016. 'Why Anti-Chinese Sentiment in Africa is on the Rise'. Sixth Tone, 18 July 2016. (http://www.sixthtone.com/ news/why-anti-chinese-sentiment-africa- rise). Accessed 15 September 2016.

Aljazeera. 2016. 'Anti-China sentiment flares up in Vietnam' 15 March 2016. (http://www.aljazeera.com/news/2016/03/ vietnam-south-china-sea-tensions-rise- 160314072842269.html). Accessed 15 September, 2016.

Altheide, D.L. 2002. Creating Fear; News and the construction of crisis. NY:Aldine De Gruyter.

Armstrong, M. 2012. 'Disturbing the peace: riots and the working class.' Marxist Left Review (4). Accessed 15 January 2015. http://marxistleftreview.org/index.php?option=com_content\&view=article\&id=82: disturbing-the-peace-riots-and-theworking-class\&catid=41:number-4-winter-2012\&ltemid=80.

Benton, G. and Gomez, E. 2014. 'Belonging to the nation: generational change, identity and the Chinese diaspora.' Ethnic and Racial Studies, 37 (7): 1157-1171. doi: 10.1080/01419870.2014.890236.

Bin Wu and Hong Liu. 2014. 'Bringing class back in: class consciousness and solidarity among Chinese migrant workers in Europe and the UK.' Ethnic and Racial Studies, 37 (8): 1391-1408. doi: 10.1080/01419870.2012.715660.

Birrell, B. and Healy, E. 2013. 'Melbourne's high rise apartment boom.' Centre for Population and Urban Research Research Report September 2013. Accessed January 16, 2015.http://artsonline.monash.edu.au/cpur/files/2013/09/high-riseboom.pdf.

Bourke, L. 2017. 'Malcolm Turnbull defends saying wealthy parents should shell out to buy their kid a house.' Accessed 7 February 2018. http://www.smh.com.au/federal-politics/political-news/malcolm-turnbull-defends-saying-wealthyparents-should-shell-out-to-buy-their-kid-a-house-20160504-goml5z.html.

Brett, J. and Moran, A. 2011. 'Cosmopolitan nationalism: ordinary people making sense of diversity.' Nations and Nationalism, 17 (1): 188-206.

Burnside, S. 2010. 'Is Mining truly good for indigenous people?’ Accessed 17 January 2015. Newmatilda.com. https:// newmatilda.com/2010/06/22/mining-truly- good-indigenous-people.

Cai, P. 2014. ‘Clive Palmer’s dangerous Chinese misstep.' 2 June 2014. Accessed 18 January, 2015. http://www. businessspectator.com.au/article/2014/6/2/china/clive-palmers- dangerous-chinese-misstep.

Chew, E. 2016. 'Bloody Hell Australia It's racist to call Asians gooks...' YOMYOMF 20 June 2016.https://www.yomyomf.com/ bloody-hell-australia-its- racist-to-call-asians-gooks/accessed 15 September, 2016.

Cox, L. 2014. 'Passports of Australian jihadists cancelled, say Julie Bishop.' The Sydney Morning Herald. June 222014. Accessed 15 January 2015.http://www.smh.com.au/federal-politics/political-news/passports-of- australian-jihadistscancelled-says-julie-bishop-20140622-3aly1.html.

Curthoys, A., and Markus, A., (Eds.) 1978. Who are our enemies? Racism and the Australian working class, Neutral Bay: Hale and Ironmonger.

Dow, A. 2015. 'Investigator to probe Melbourne’s “sophisticated” illegal rooming networks' The Age 28 June 2015. Accessed 15 September 2016. http://www.theage.com.au/victoria/investigator- to-probe-melbournes-sophisticated-illegalrooming-networks-20150628- ghzpd0.html.

Finnane, M. 2014. 'Habeas Corpus Mongols' - Chinese litigants and the politics of immigration in 1888.' Australian Historical Studies, 45 (2): 165-183. doi: 10.1080/1031461X.2014.911759.

Fitzgerald, J. 2007. Big white lie: Chinese Australians in white Australia. Sydney: University of NSW Press.

Foster, L. and Stockley, D. 1984. Multiculturalism: The changing Australian paradigm. Avon: Multilingual Matters.

Furedi, F. 1997. The culture of fear; risk taking and the morality of low expectations. London: Cassell.

Greene, A. 2017. 'Prominent Australian academic says he's been silenced by Chinese Government.' Accessed 8 February. http://www.abc.net.au/news/2017-11-13/academic-claims-hes-been-silenced-by-chinese-government/9142694.

Hage, G. 1998. White nation: Fantasies of white supremacy in a multicultural society. Annandale: Pluto Press.

Hage, G. 2003. Against paranoid nationalism: Searching for hope in a shrinking society, Annandale: Pluto Press.

Hunt, L. 2016. Australia long tied to China by “fear and greed”, boots defense amidst increased skepticism' The Washington Times 30 May, 2016,

Jakubowicz, A. 2011. Chinese walls: Australian multiculturalism and the necessity for human rights, Journal of Intercultural Studies, 32:6, 691-706, DOI:10.1080/07256868.2011.618111.

Jakubowicz, A. 2015. 'New Multicultural Council signals a broader shift to the right.' The Conversation. Accessed 7 January, 2015. http://theconversation.com/new-multicultural-council-signals-a-broader-shift-to- the-right-35815. 
Jericho, G. 2014. 'Strap yourselves in, this could get bumpy.' The Drum ABC. Accessed 18 January, 2015. http://www.abc.net. au/news/2014-09-24/jericho-strap-yourselves-in-this-could-get-bumpy/5764004.

Kelly, P. 2013. 'Mining tax probe is more water torture for Gillard.' The Australian February 272013. Accessed 19 January, 2015. http://www.theaustralian.com.au/opinion/columnists/mining-tax-probe-is-more- water-torture-for-gillard/storye6frg74x-1226586348900.

Kymlicka, W. 2010a. The rise and fall of multiculturalism? New debates on inclusion and accommodation in diverse societies. International Social Science Journal, $19997-112$.

2010b. Testing the liberal multiculturalist hypothesis: normative theories and social science evidence. Canadian Journal of Political Science 43 (2): 257 - 271.

Laurenceson. J. 2014. 'Zombie economics: the notion China is to blame for Australia's property bubble refuses to die." The Conversation 14 October 2014. Accessed 15 February, 2018. http://theconversation.com/zombie-economics-the-notionchina-is-to-blame-for-australias-property-bubble-refuses-to-die-32455.

Lentin, A. 2014. Post-race, post politics: the paradoxical rise of culture after multiculturalism. Ethnic and Racial Studies, 37 (8): 1268-1285. doi:10.1080/01419870.2012.664278.

Markus, A. 2015. Mapping Social Cohesion; The Scanlon Foundation Surveys 2015. Caulfield East: Monash University.

Meer and Modood, T. 2014. Cosmopolitanism and integrationism: is British multiculturalism a 'Zombie category'? Identities: global studies in culture and power, 21 (6): 1 - 17. doi: 10.1080/1070289X.2013.875028.

Moran, A. 2011. Multiculturalism as nation-building in Australia: Inclusive national identity and the embrace of diversity. Ethnic and Racial Studies, 34 (12); 2153-2172. doi: 10.1080/01419870.2011.573081.

Mulligan, M. 2016. 'Our complex relationship with the Chinese Australians'. Australian Financial Review. 9 January 2016. Accessed 15 February 2018. http://www.afr.com/business/our-complex-relationship-with-chinese-australians20151227-glvgml.

Palmer, C. 2014. Q and A, ABC. Accessed 15 January, 2015. 2015http://www.abc.net.au/tv/qanda/vodcast.htm.

Papadopoulos, G. \& Moraitis, S. 2006 Australian Greek Welfare Society: Twenty Years, Melbourne: AGWS. Accessed 17 January, 2015. http://agws.com.au/history.asp.

Poynting, S. 2006. What caused the Cronulla riot? Race Class, 48 (1): 85 - 92. doi: 10.1177/030639680604800116.

Rudd, K. 2011. 'The rise of the Asia Pacific and the role of creative middle power diplomacy' Professor Bernt Seminar Series, Oslo University, 19 May 2011. Accessed 14 January 2015. http://foreignminister.gov.au/speeches/Pages/2011/kr_ sp_110519.aspx?ministerid=2.

Selth, P. 1974. The Burrangong (Lambing Flat) Riots 1860-61: A Closer Look. Journal of the Royal Australian Historical Society, 60: 48-69.

Skol, G. 2010. Social Theory of Fear; terror, torture, and death in a post-capitalist world. NY: Palgrave Macmillan.

Sydney Morning Herald. 2017. 'Payments, power and our politicians'. Accessed 15 February 2018. http://www.smh.com.au/ interactive/2017/chinas-operation-australia/hard-power.html.

Tasch, B. 'Anti-China sentiment is suddenly sweeping over Turkey’ Business Insider UK. 15 July 2015. (http:// uk.businessinsider.com/china-turkey-uighurs- 2015-7? r=US\&IR=T) Accessed 15 September, 2016.

Tsolidis, G. 2014. Does the new doxa of integrationism make multicultural education a contemporary heresy? In H. Proctor, P. Brownlee \& P. Freebody (Eds.) Educational Heresies: New and enduring controversies over practice and policy. Netherlands: Springer, 113-127.

Tudor, A. 2003. ‘A (macro) sociology of fear?’ Sociological Review, 51 (2): 238-256.

Van Krieken, R. 2012. 'Between assimilation and multiculturalism: models of integration in Australia.' Patterns of Prejudice, 46 (5): 500-517. doi:10.1080/0031322X.2012.718167.

Van Reekum, R., Duyvendak, J. and Bertossi, C. 2012. Patterns of Prejudice, 46 (5): 417-426. doi: 10.1080/0031322X.2012.718162.

Vedelago, C. and Houston, C. 2015. 'No stop to slums in the sky' The Age, 3 May 2015. Accessed 18 February, 2016. http:// www.theage.com.au/victoria/no-stop-to-slums-in-the-sky-20150502-1myf98.html.

Welch, I. 2003. Alien Son: The life and times of Cheok Hong Cheong, (Zhang Zhuoxiong)1851 - 1928. Unpublished PhD, Canberra:ANU.

Yeh, D. 2014. 'Contesting the 'model minority': racialization, youth culture and 'British Chinese'/'Oriental' nights.' Ethnic and Racial Studies, 37 (7):1197-1210. doi: 10.1080/01419870.2014.859288.

Yuan, J. 2014. A rising power looks down under: Chinese perspectives on Australia. Barton: ASPI. 